\title{
Analyzing the Labours of Hercules
}

\author{
Alireza Nabilou* \\ Associate Professor of Persian Language and Literature, University of Qom \\ *Corresponding author: dr.ar_nabiloo@yahoo.com
}

Received July 10, 2014; Revised August 27, 2014; Accepted September 27, 2014

\begin{abstract}
In this research, Labours of Hercules has been studied from the viewpoint of Greimas. Features of story have been explained and then narration and narratology has been studied. Greimas is one of the narratologists who modified Propp's theory about seven scops of fictional actions and mentioned new attitude for studying structure of narration by mentioning six actants (Object/subject; sender/receiver; helper/ Opposer). He also introduced three separate sequences in narration which were known as contractual, the performative and the disjunctive. By studying this story from the viewpoint of Greimas, we find valuable points. In this narration, Hercules is subject and the goals are expiation, atone and immortalize. Senders are Eurystheus and oracle Pythoness. Hercules is helped by Thespius, Athena, Iolaus, Artemis, Atlas, Zeus, Hermes etc. Hera, Nessus, creatures and agents in Labours decide to fight against Hercules and defeat him. Sender and receiver are common in labours of Hercules; Eurystheus is Sender and Receiver. As we see, Hercules is Receiver and Subject. Of other issues of Greimas which have been studied in this story are three narrative sequences i.e. contractual, the performative and the disjunctive and as shown, these sequences are available in the discussed story. Therefore it is proved based on Greimas' theory that Labours of Hercules has fixed design and pattern and systematic narrative structure.
\end{abstract}

Keywords: Labours of Hercules, narration, Greimas’ theory, actant, narrative sequences

Cite This Article: Alireza Nabilou, “Analyzing the Labours of Hercules.” American Journal of Educational Research, vol. 2, no. 10 (2014): 876-882. doi: 10.12691/education-2-10-5.

\section{Introduction}

To study structure of this story, different forms and methods can be applied that is formative elements of story can be studied from different perspectives; the elements such as character, narrator, action, ethical results, extraordinary events, classification of stories characters, narrators, actantial and non- actantial stories, mentioning the most important ethical results, referring to leitmotifs of stories and specifying time and space coordinates are among these classes. In this paper, the goal is not to study elements of the story but study its narrative structure as Greimas' theory. It is necessary to note that this type of new attitude to traditional work will receive new cases and study literature systematically and methodologically and helps recognize new theories and its application in traditional and contemporary literature.

\subsection{Methodology}

The author has used a descriptive-analytical methodology in this study. All the investigations were done by conducting desk and library research as well as by analyzing and classifying investigations. All of these investigations -along with an analysis of Labours of Hercules- are divided into distinct categories and distinguished based on Greimas’ theory.

\subsection{Literature Review}

Although much has been written about Labours of Hercules analysis, as well as books and articles are provided on the theory of Greimas, However, we have not any book and article on analyzing the story of Hercules from the perspective of Greimas, and the following books, only mentioned to the general discussion of narrative and we can find the description of the theory of Greimas in these books.

1. The Grammar of Story; in this book, good points have been mentioned about narration and grammar of story and Greimas' theory has been also included in this work (refer to: Okhovvat, 1992: most of the pages)

2. Narratology: a linguistic-critical introduction; in this work, different narratological theories have been explained. Of course, Greimas' theory has been summarized (refer to: Toolan, 2007: most pages).

3. Narration theories; in this book, narralogists and their theories are studied (refer to: Martin, 2007: most pages).

4. Literary Theory the Basics; in this book, different narratological theories have been explained (refer to: Bertens, 2005: 69).

5. Literary Theory; in this book, narralogists and their theories are studied (refer to: Eagleton, 2004: most pages).

6. A readers Guide to Contemporary Literary Theory; in this work, different narratological theories have been explained (refer to: Selden and Widdowson, 2005: 143).

These references majorly pay attention to generality of narration and structuralism. In these references, some theories of Greimas are summarized, of course, the work which directly studied narrative structure of this narration 
has not reached result and the present article is new from this viewpoint.

\section{Labours of Hercules}

The twelve Labours of Hercules; Labours were Hercules - the most famous hero in Greek mythologymissions, to atone for his sin (murder his wife and children), that he has been successfully accomplished. Separate stories that later turned into a unified story. The Greeks believed that the collection and integration narrative of this story attributed to Peisandr, (Greek epic poet was about 600 years BC). For more clarity of the subject, we first mention summary of this story:

\subsection{Summary of the Discussed Story}

The twelve labours of Hercules are a series of episodes concerning a penance carried out by the greatest of the Greek heroes, Hercules. The episodes were later connected by a continuous narrative. The establishment of a fixed cycle of twelve labours was attributed by the Greeks to an epic poem, now lost, was written by Peisander (about 600 BC). Driven mad by Hera, Hercules slew his six sons and wife. After recovering his sanity, Hercules deeply regretted his actions; he was purified by King Thespius then traveled to Delphi to inquire how he could atone for his actions. There the oracle Pythoness advised him to reside at Tyrins and serve King Eurystheus for twelve years, performing whatever labour might beset him; in return, he would be rewarded with immortality. Hercules despaired at this, loathing to serve a man whom he knew to be far inferior, yet afraid to oppose his father Zeus. Eventually he placed himself at Eurystheus's disposal. Eurystheus ordered Hercules to perform ten labours. Hercules accomplished these tasks, but Eurystheus refused to recognize two: the cleansing of the Augeas, because Hercules was going to accept pay for the labour; and the killing of the Lernaean Hydra, as Hercules' nephew and charioteer Iolaus had helped him. Eurystheus set two more tasks (fetching the Golden Apples of Hesperides and capturing Cerberus), which Hercules performed successfully, bringing the total number of tasks to twelve.

1. Nemean lion: According to one version of the myth, the Nemean lion took women as hostages to its lair in a cave near Nemea, luring warriors from nearby towns to save the damsel in distress. After entering the cave, the warrior would see the woman (usually feigning injury) and rush to her side. Once he was close, the woman would turn into a lion and kill the warrior, devouring his remains and giving the bones to Hades. Hercules wandered the area until he came to the town of Cleonae. There he met a boy who said that if Hercules slew the Nemean lion and returned alive within thirty days, the town would sacrifice a lion to Zeus, but if he did not return within thirty days or he died, the boy would sacrifice himself to Zeus. Another version claims that he met Molorchos, a shepherd who had lost his son to the lion, saying that if he came back within thirty days, a ram would be sacrificed to Zeus. If he did not return within thirty days, it would be sacrificed to the dead Heracles as a mourning offering. While searching for the lion, Hercules fletched some arrows to use against it, not knowing that its golden fur was impenetrable; when he found and shot the lion and firing at it with his bow, he discovered the fur's protective property when the arrow bounced harmlessly off the creature's thigh. After some time, Hercules made the lion return to his cave. The cave had two entrances, one of which Hercules blocked; he then entered the other. In those dark and close quarters, Hercules stunned the beast with his club and, using his immense strength, strangled it to death. During the fight the lion bit off one of his fingers. Others say that he shot arrows at it, eventually shooting it in the unarmored mouth. After slaying the lion, he tried to skin it with a knife from his belt, but failed. He then tried sharpening the knife with a stone and even tried with the stone itself. Finally, Athena, noticing the hero's plight, told Heracles to use one of the lion's own claws to skin the pelt. Others say that Hercules' armor was, in fact, the hide of the lion of Cithaeron. When he returned on the thirtieth day carrying the carcass of the lion on his shoulders, King Eurystheus was amazed and terrified. Eurystheus forbade him ever again to enter the city; in future he was to display the fruits of his labours outside the city gates. In future, Eurystheus told Hercules his tasks through a herald, not personally. Eurystheus even had a large bronze jar made for him that he could hide in from Heracles if need be. Eurystheus then warned him that the tasks set for him would become increasingly difficult. He then sent Hercules off to complete his next quest, which was to destroy the Lernaean hydra.

2. Lernaean hydra: After slaying the Nemean lion, Eurystheus sent Hercules to slay the Hydra, which Hera had raised just to slay Hercules. Upon reaching the swamp near Lake Lerna, where the Hydra dwelt, Hercules covered his mouth and nose with a cloth to protect himself from the poisonous fumes. He fired flaming arrows into the Hydra's lair, the spring of Amymone, a deep cave that it only came out of to terrorize neighboring villages. He then confronted the Hydra, wielding a harvesting sickle a sword or his famed club. Ruck and Staples have pointed out that the chthonic creature's reaction was botanical: upon cutting off each of its heads he found that two grew back, an expression of the hopelessness of such a struggle for any but the hero. The weakness of the Hydra was that only one of its head was immortal. He could not defeat the Hydra in this way, Hercules called on his nephew Iolaus for help. His nephew then came upon the idea of using a firebrand to scorch the neck stumps after each decapitation. Hercules cut off each head and Iolaus cauterized the open stumps. Seeing that Hercules was winning the struggle, Hera sent a large crab to distract him. He crushed it under his mighty foot. The Hydra's one immortal head was cut off with a golden sword given to him by Athena. Hercules placed it under a great rock on the sacred way between Lerna and Elaius, and dipped his arrows in the Hydra's poisonous blood, and so his second task was complete. The alternative version of this myth is that after cutting off one head he then dipped his sword in it and used its venom to burn each head so it couldn't grow back. Hera, upset that Hercules slew the beast she raised to kill him, placed it in the dark blue vault of the sky as the Constellation Hydra. She then turned the crab into the Constellation Cancer. Hercules later used an arrow dipped in the Hydra's poisonous blood to kill the centaur Nessus; and Nessus's tainted blood was applied to the Tunic of Nessus, by which the centaur had his posthumous revenge. 
Both Strabo and Pausanias report that the stench of the river Anigrus in Elis, making all the fish of the river inedible, was reputed to be due to the Hydra's poison, washed from the arrows Heracles used on the centaur.

3. Ceryneian Hind: Eurystheus and Hera were greatly angered to find that Hercules had managed to escape from the claws of the Nemean Lion and the fangs of the Lernaean Hydra, and so decided to spend more time thinking up a third task that would spell doom for the hero. The third task did not involve killing a beast, as it had already been established that Hercules could overcome even the most fearsome opponents, so Eurystheus decided to make him capture the Ceryneian Hind, as it was so fast it could outrun an arrow. After beginning the search, Hercules awoke from sleeping and he could see the hind from the glint on its antlers. Hercules then chased the hind on foot for a full year through Greece, Thrace, Istria and the land of the Hyperboreans. In some versions, he captured the hind while it slept, rendering it lame with a trap net. In other versions, he encountered Artemis in her temple and she told him to leave the hind and tell Eurystheus all that had happened and his third labor would be considered to be completed. Yet another version claims that Heracles trapped the Hind with an arrow between the forelegs of the creature. Eurystheus had given Hercules this task hoping to incite Artemis' anger at Hercules for his desecration of her sacred animal. As he was returning with the hind, Hercules encountered Artemis and her brother Apollo. He begged the goddess for forgiveness, explaining that he had to catch it as part of his penance, but he promised to return it. Artemis forgave him, foiling Eurystheus' plan to have her punish him. Upon bringing the hind to Eurystheus, he was told that it was to become part of the King's menagerie. Hercules knew that he had to return the hind as he had promised, so he agreed to hand it over on the condition that Eurystheus himself come out and take it from him. The King came out, but the moment Hercules let the hind go, it sprinted back to its mistress, and Heracles left saying that Eurystheus had not been quick enough. Eurystheus, upset that Heracles had managed to overcome yet another creature, told him to bring the fearsome Erymanthian Boar back to him alive.

4. Erymanthian Boar: Hercules' fourth labour was to capture the Boar. On the way there, Hercules visited Pholus, a kind and hospitable centaur and old friend. Hercules ate with him in his cavern and asked for wine. Pholus had only one jar of wine, a gift from Dionysus to all the centaurs on Mt. Erymanthos. Hercules convinced him to open it, and the smell attracted the other centaurs. They did not understand that wine needs to be tempered with water, became drunk, and attacked. Hercules shot at them with his poisonous arrows, and the centaurs retreated all the way to Chiron's cave. Pholus was curious why the arrows caused so much death, and picked one up but dropped it, and the arrow stabbed his foot, poisoning him. Chiron was immortal, although he still felt the pain. Chiron's pain was so great, he volunteered to give up his immortality, and take the place of Prometheus, who had been chained in to the top of a mountain to have his liver eaten daily by an eagle, although he was an immortal Titan. Prometheus' torturer, the eagle, continued its torture on Chiron, so Hercules shot it dead with an arrow. Hercules had visited Chiron to gain advice on how to catch the boar, and Chiron had told him to drive it into thick snow, which sets this Labour in mid-winter. Having successfully caught the Boar, Hercules bound it and carried it back to Eurystheus, who was frightened of it and ducked down in his half-buried storage pithos, begging Heracles to get rid of the beast. Three days later, Eurystheus, still trembling with fear, sent Hercules to clean the Augean stables.

5. Augean stables: The fifth Labour of Hercules was to clean the Augean stables. This assignment was intended to be both humiliating and impossible, since the livestock were divinely healthy and therefore produced an enormous quantity of dung. These stables had not been cleaned in over 30 years, and over 1,000 cattle lived there. However, Hercules succeeded by rerouting the rivers Alpheus and Peneus to wash out the filth. Augeas was irate because he had promised Hercules one tenth of his cattle if the job was finished in one day. He refused to honour the agreement on the grounds that Hercules had been ordered to carry out the task by Eurystheus anyway, and Hercules killed him after completing the tasks. Hercules gave his kingdom to Augeas' son Phyleus, who had been exiled for supporting Hercules against his father. Eurystheus, stating that Heracles still had seven Labours to perform, then sent Hercules to defeat the Stymphalian Birds.

6. Stymphalian Birds: After cleaning the Augean Stables, Eurystheus sent Hercules to defeat the Stymphalian birds, man-eating birds with beaks of bronze and sharp metallic feathers they could launch at their victims; they were sacred to Ares, the god of war. Furthermore, their dung was highly toxic. They had migrated to Lake Stymphalia in Arcadia, where they bred quickly and took over the countryside, destroying local crops, fruit trees and townspeople. Hercules could not go too far into the swamp, for it would not support his weight. Athena, noticing the hero's plight, gave Heracles a rattle which Hephaestus had made especially for the occasion. Hercules shook the rattle and frightened the birds into the air. Hercules then shot many of them with his arrows. The rest flew far away, never to return.

7. Cretan Bull: Hercules was then sent to capture the bull by Eurystheus as his seventh task. He sailed to Crete, whereupon the King Minos, gave Hercules permission to take the bull away and offered him assistance which Hercules declined because of pride. Hercules snuck up behind the bull and then used his hands to throttle it, and then shipped it back to Athens. Eurystheus, who hid in his pithos at first sight of the creature, wanted to sacrifice the bull to Hera, who hated Hercules. She refused the sacrifice because it reflected glory on Heracles.

8. Mares of Diomedes: After capturing the Cretan bull, Hercules was to steal the Mares. Hercules was not aware that the horses, called Podagros (the fast), Lampon (the shining), Xanthos (the blond) and Deinos (the terrible), were kept tethered to a bronze manger because they were wild; their madness being attributed to an unnatural diet of human flesh. They were man-eating and uncontrollable, and Hercules left his favoured companion, Abderus, in charge of them while he fought Diomedes, and found out that the boy was eaten. In revenge, Hercules fed Diomedes to his own horses; then founded Abdera next to the boy's tomb.

9. Belt of Hippolyta: Eurystheus' daughter Admete wanted the belt of Hippolyta, a gift to the queen of the 
Amazons from the war god Ares. To please his daughter, Eurystheus ordered Heracles to retrieve the belt as his ninth labour. Hippolyta impressed with Hercules and his exploits, agreed to give him the belt and would have done so had Hera not disguised herself and walked among the Amazons sowing seeds of distrust. She claimed the strangers were plotting to carry off the queen of the Amazons. Alarmed, the women set off on horseback to confront Hercules. When Hercules saw them, he thought Hippolyta had been plotting such treachery all along and had never meant to hand over the belt, so he killed her and took the belt, returning to Eurystheus. Eurystheus, shocked that Hercules survived his encounter with the Amazons, immediately sent him to capture the cattle of Geryon.

10. Cattle of Geryon: Heracles was required to travel to the far-off western Mediterranean island of Erytheia, in order to obtain the Cattle of Geryon as his tenth labour. On the way there, he crossed the Libyan deserts and became so frustrated at the heat that he shot an arrow at Helios, the Sun. Helios "in admiration of his courage" gave Hercules the golden cup he used to sail across the sea from west to east each night. Hercules used it to reach Erytheia. When Hercules reached Erytheia, no sooner had he landed than he was confronted by the two-headed dog, Orthrus. With one huge blow from his olive-wood club, Heracles killed the watchdog. Eurytion the herdsman came to assist Orthrus, but Hercules dealt with him the same way. On hearing the commotion, Geryon sprang into action, carrying three shields, three spears, and wearing three helmets. He pursued Hercules at the River Anthemus but fell victim to an arrow that had been dipped in the venomous blood of the Lernaean Hydra, shot so forcefully by Heracles that it pierced Geryon's forehead. Hercules then had to herd the cattle back to Eurystheus.

11. Apples of the Hesperides: After Hercules completed his first ten Labours, Eurystheus gave him two more claiming that neither the Hydra counted (because Iolaus helped Hercules) nor the Augean stables (either because he received payment for the job or because the rivers did the work); The first of these two additional Labours was to steal the apples from the garden of the Hesperides. Finally making his way to the Garden of the Hesperides, Hercules tricked Atlas into retrieving some of the golden apples for him, by offering to hold up the heavens. This would have made this task - like the Hydra and Augean stables - void because he had received help. Upon his return, Atlas decided that he did not want to take the heavens back, and instead offered to deliver the apples himself, but Hercules tricked him again by agreeing to take his place on condition that Atlas relieve him temporarily so that Hercules could make his cloak more comfortable. Atlas agreed, but Hercules reneged and walked away, carrying the apples.

12. Cerberus: Capturing Cerberus alive, without using weapons, was the final labour assigned to Hercules by Eurystheus. Hercules went to Eleusis to be initiated in the Eleusinian mysteries so that he could learn how to enter and exit the underworld alive, and in passing absolve himself for killing centaurs. He found the entrance to the underworld at Tanaerum, and Athena and Hermes helped him to traverse the entrance in each direction. Hercules found Hades and asked permission to bring Cerberus to the surface, which Hades agreed to if Hercules could overpower the beast without using weapons. Hercules was able to overpower Cerberus and proceeded to sling the beast over his back, dragging it out of the underworld through a cavern entrance in the Peloponnese and bringing it to Eurystheus. The king again fled into his pithos, and asked Hercules to return it to the underworld in return for releasing him from his labors. After completing the labours Heracles joined the Argonauts in the search for the Golden Fleece. (Adapted and summarized from: DixonKennedy, 2006 and Warner, 2004)

\section{Greimas}

Algirdas Julien Greimas was born in 1917 in Lithuania, but later, this prominent semiotician and linguist adopted French citizenship. He had a degree in linguistics and graduated in 1939 from the University of Grenoble (a city in southern France). He received his $\mathrm{PhD}$ in the same field in 1949 from the Sorbonne.

Greimas was founder and Secretary General of the International Association of Semiotics Studies. He eventually died in Paris (1992) and was buried beside the grave of his parents in Lithuania.

\section{Narratological Theory of Greimas and Discussed Narration}

Formalists were the first persons who studied narration and narrative structures. They intended to discover rules and formulas to study structure of stories on its basis. They considered literature scientifically and mathematically. As formalists analyzed sentences into analyzable components and morphemes in the field of lingual structure studies, they sought to discover special patterns through analysis. After formalists, structuralists like Greimas, Todorov, Genette and Bremond studied narration and its structures. In this type of analyses, details and elements of story are not considered much because the researcher intends to discover common sequence patterns and themes of the stories. Like Greimas and others, Todorov believes that narration is only a set of lingual facilities which have gathered in special way based on a set of grammatical structural rules (Schols, 2004; 160). In principle, charcaters and events in ancient stories expand themes and leitmotifs as Propp has proved this fact in analysis of Russian stories. Propp achieved leitmotifs by analyzing content of about 100 Russian folklore stories (Guiraud, 2004: 109). In study of the structures, most emphasis is on hidden relations among structures of a text. Structuralism means study of interactions between constituent parts of a folklore object or subject. [Structuralism] is not only limited to folklore and legend stories. Structuralistic method can be applied for any subject (Propp, 1989: 7). One of the features of structures is that they are hidden or invisible which should be discovered. Structures are not the subjects which can be directly encountered but they are systems of the hidden relations, are more perceived than received. (Sojoodi, 2004: 154). In structuralistic analysis of narration, details of internal mechanisms of literary texts are studied to discover fundamental structural units or performances (such as personality performance) governing narrative 
functions of texts (Tyson, 2008: 364). In narratology, different aspects of narration are studied but despite difference of opinions among the narratologists, final aim of all of them is to discover comprehensive narration pattern which supervises on linguistic form of narrations and their describable structure and also considers relations among persons and formation of the narration. The most important theorists in narratology include Vladimir Propp, Algirdas Julius Greimas, Tzvetan Todorov, Gérard Genette and Roland Barthes.

Algirdas Julius Greimas (1917 to 1992) is one of the persons who made innovations in recognition of narration structures. He tends to semiology in terms of intellectual fundamentals and on the other hand, he has theoretical dependency on France structuralism. Greimas regards narration structure very close to grammatical structure of language and finds the stories affected by a pattern and structure despite their differences. What is important for Greimas is infrastructural and constructive grammar of narrations not individual extremity. In addition, Greimas believes that narration rule is limited like grammatical rule. Effort to find a description of narrations rule is one of the most important structuralism actions (Green and Lebihan, 2004; 110). This comprehensive structural pattern also includes narrative structures in addition to story. Greimas means to achieve global grammatical rule of narration by utilizing semantic analysis of the sentence structure (Selden, 2005: 144).

He pays much attention to role of dual contrasts in story and narration due to semiology. This dual contrast is found in two forms in Greimas pattern: subject and object /sender and receiver /helper and opponent.

According to Greimas, implication starts with binary opposition. It is necessary to have at least 2 partners in sequence of any narration and base actions include disjoining and joining, breakup and renewal of friendship. Narration mainly means transfer of a value or object from a partner to another partner (Schols, 2004; 147). Greimas starts his work with fundamental concept of binary opposition which is main nature of human perception. Any sequence of narration materializes this perceptual nature using two factors of action which should be reciprocal or reverse. This reciprocal or opposite relation creates reciprocal or opposite relation which is fundamental action of discontinuity and continuity, disconnection and connection, breakup and renewal of friendship (Sojoodi, 2005; 66). The fact that Greimas emphasizes is that all six elements may not be present in a narration and one of the elements may play dual role. Greimas tried to modify the Propp’s model by mentioning its agent pattern and evaluate narrations from another viewpoint. Algirdas Julius Greimas in book "Semantic Structure" (1966) could summarize his work by perceiving Propp's design using concept of agent. This concept is neither a special story nor even a character but a structural concept. Considering six actors of objet and subject, sender and receiver, helper and enemy, one can deduce different scopes of action suggested by Propp and even achieve more beautiful simplicity (Eagleton, 2004: 144). Therefore, Greimas regard these six agents opposite to seven characters of Propp i.e. malicious, generous and provider, helper, searched person and his father, dispatcher, heroes, false hero. According to Greimas, Propp's attitude is involved in theme and is not structural enough. As a result, he mention an agent model which is abstract and should be able to describe narration in the general sense and specify all potential elements and types of combinations of these elements in literary and nonliterary texts (Bertens, 2005: 85).

As mentioned above, Greimas regards six roles or agents as basis of study of narration structure. According to Greimas, six functional roles and fixed relations between them comprise main framework of all narrations (Ibid; 86). As we saw, Propp thinks that events of the story have distinguished role but Greimas believes that the role is given to characters and Greimas makes evaluation with focus on this narrative element. Greimas suggests reverse of the Greimas' model in which events are consequent to character. He suggests that only six roles or six agents as he interprets are present in infrastructure of all narrations as general categories which comprise three related pairs: donor +receiver; subject +object ; helper +competitor (Toolan, 2007, 150). Subject is central element of action of the story that is a person or thing which performs an action; object is the thing which subject seeks to achieve with actions, anything which is on the way of reaching object is anti-hero or competitor; sender sends subject or agent to find the recognition subject or object, receiver will have this search; two forces of helper and opponent intend to help and prevent among them. As we see, agent relates to character and can include persons, objects or other affairs. This model [6 agents] is considerably compatible with design of many traditional folk stories and fairy stories. Despite simplicity of this model as well as need for different explanations of it to adapt to different literary types, this design can be applied usefully for a scope of texts (Ibid; 151).

Considering difference of agents in Labours of Hercules, pay attention to the following table:

Table 1. Actants of Narration in the Framework of Greimas' Theory

\begin{tabular}{|c|c|}
\hline Actants & Hercules \\
\hline Sender & Eurystheus, oracle Pythoness \\
\hline Receiver & Hercules, Eurystheus, Hera \\
\hline Subject & Hercules \\
\hline Object & Hercules would be rewarded with immortality, Expiation and atone for the killing of his sons and wife \\
\hline Helper & Thespius, Athena, Iolaus, Artemis, Atlas, Zeus, Hermes \\
\hline Opposer & Hera, Nessus, creatures and agents in Labours of Hercules \\
\hline
\end{tabular}


Table 2. Relations between actants

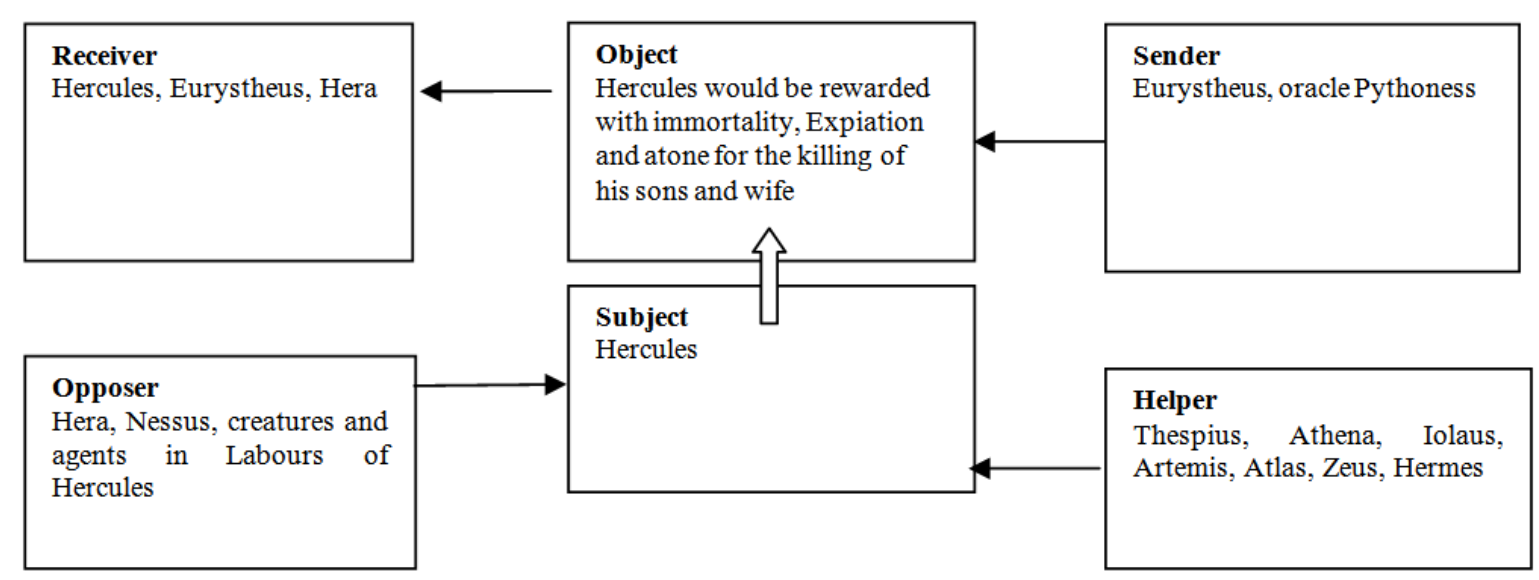

The studied story can be classified and coded considering the presence or absence of one of six actants introduced by Greimas. (Bertens, 2005; 85) In some stories, all six actants are present and in some of them, one or two cases of these six actants are absent. (Okhovvat, 1992; 146) This case doesn't reduce value of this research because Greimas has known the presence of such feature and absence of one or more actants and their integration with each other. (Selden, 2005; 143) Sender/receiver and subject /object are four actants which are thought by Greimas "to be provided in some narrations only with two actants" (Scholes, 2004; 150). Considering simplicity of the stories in terms of plot and other fictional elements, it is better to pay attention to relations of persons, heroes and narrative patterns governing among them because "characters and heroes are changed less in story and almost are exposed to different events" (Mir Sadeghi, 1986; 71).

Considering that the Greimas' approach is holistic to partial, his method is a good model for thinking more about all kinds of characters. "Greimas considers relations between these natures instead of dealing with nature of the characters" (Selden, 2005; 144). This case is studied better considering simplicity and lack of story writing technique in them and allows researcher to pay attention to relations among them instead of characters.

The story mentioned in this research is summarized based on Greimas' Pattern according to the following sequence to gain general view of the stories and better explain position of six actants of Greimas in them: sender +subject or knower +object +helper +opponent +receiver.

In fact, basis of this classification and their diversity are affected by Greimas’ attitude because he based his theory on binary oppositions and regarded them as the main factor of narrations formation. (Bertens, 2005; 77) He has placed subject versus object, sender versus receiver and helper versus competitor. In fact, subject corresponds to hero of story and object corresponds to the searched person or desirable target and these two agents play central role in narration. (Eagleton, 2004; 144) It means that two pairs of subject and object (goal) are the most fundamental pair of narration and create main action of story and progression of narration. For this reason, two agents of subject and object are present in all stories and all stories contain them. (Toolan, 2007; 151) On the other hand, although receiver is in the margin of narration, it overlaps with subject in some stories and is sometimes the subject itself because the subject which is also receiver receives the final benefit.

As seen above, Hercules is subject and the goals are expiation, atone and immortalize. Senders are Eurystheus and oracle Pythoness. In this story, Hercules is helped by Thespius, Athena, Iolaus, Artemis, Atlas, Zeus, Hermes etc. In this story, Hera, Nessus, creatures and agents in Labours decide to fight against Hercules and defeat him. Helpers and opposers (competitors) act to reach the goal in favor of or against subject. In the stories, the presence of helper indicates that success of agent, reaching goal, hopefulness and happy end of story are considered more. The presence of competitor delays victory and delay in achieving the goal. On the other hand, Helper and competitor relation focuses on power and its exercise and in each story which one of these two is present; they are effective on success or failure of subject and accelerate or delay this case. Sender and receiver are common in labours of Hercules; Eurystheus is Sender and Receiver. As mentioned above, Hercules is Receiver and Subject.

One of the other narratological issues of Greimas is to pay attention to narrative sequences which he thinks to be studied in three classes: "executive, conventional and discontinuous”. (Seldan, 2005; 144) To complete grammar of the narration, list of syntactic structures or narrative structuring principles is needed and Greimas has studied this case by presenting these three separate sequences:

1. Performative (tests and struggles)

2. Contractual (closing and breaking conventions )

3. Disjunctive (coming and going )

In executive sequence, tests, struggles, efforts and functions like this are studied and a part of each narration relates to these subjects and affairs and this dimension is not available in this narration. "Executive sequence makes main design of the story and narrative structure of each story relies on it” (Ahmadi, 2003; 162). In conventional sequence, treaties, promises and closing and canceling them are studied. Most of the stories have such characteristic. In discontinuous sequence, touring and coming and going are considered and most of the stories have such characteristic and story proceeds with these travels and tours. (Selden, 2005; 144)

Three narrative sequences in discussed narration:

1. Performative (tests and struggles): Hercules slew his six sons and wife; eventually he placed himself at Eurystheus's disposal; Eurystheus ordered Hercules to 
perform labours; Hercules accomplished these tasks and doing and finishing the twelve labours.

2. Contractual (closing and canceling treaties): Hercules was purified by King Thespius; Oracle Pythoness advised him to reside at Tyrins and serve King Eurystheus for twelve years; Hercules would be rewarded with immortality; Hercules afraid to oppose his father Zeus.

3. Disjunctive (coming and going): Hercules traveled to Delphi to inquire how he could atone for his actions; Going and coming that is done in the twelve labours.

\section{Conclusion}

In this paper, Labours of Hercules is selected and analyzed using narratological method and Greimas' structural analysis. Narrative analyses which are based on structuralism first start with selection of narrations and then are analyzed. In the present research, the story was selected from ancient stories for study and analysis. This case is studied better considering simplicity and lack of story writing technique in them and allows researcher to pay attention to relations among them instead of characters. As seen above, Hercules is subject and the goals are expiation, atone and immortalize. Senders are Eurystheus and oracle Pythoness. In this story, Hercules is helped by Thespius, Athena, Iolaus, Artemis, Atlas, Zeus, Hermes etc. In this story, Hera, Nessus, creatures and agents in Labours decide to fight against Hercules and defeat him. Sender and receiver are common in labours of Hercules; Eurystheus is Sender and Receiver. As mentioned above, Hercules is Receiver and Subject.

\section{References}

[1] Ahmadi, Babak. (2003). Structure and interpretation of the text, Tehran: Markaz.

[2] Bertens, Hans. (2005). Literary Theory the Basics, Trans. Mohammadreza Abolghasemi, Tehran: Mahi.

[3] Dixon-Kennedy, Mike. (2006), Encyclopedia of Greco-Roman Mythology, Trans. Roghayyi Behzadie, Tehran: Tahurie.

[4] Eagleton, Terry. (2004). Literary Theory, Trans. Abbase Mokhber, Tehran: Markaz.

[5] Green, Kaeith \& LeBihan, Jill. (2004). Critical theory and Practice: A coursebook, Trans. Goruhe Motarjeman, Tehran: Roznegar.

[6] Guiraud, Pierre. (2004). Semiologie, Trans. Mohammade Nabavi, Tehran: Agah.

[7] Harland, Richard. (2006). Literary Theory from Plato to Barthes: An Introductory history, Trans. Ali Masumi and Shapure Jowrkesh, Tehran: cheshme.

[8] Martin, Wallace. (2007) Recent Theory of Narrative, Trans Mohammade Shahba, Tehran: Hermes.

[9] Mirsadeghi, Jamal. (1986). Fiction, Tehran: Mahoor.

[10] Okhovvat, Ahmad. (1992). Story grammar, Esfahan: Farda.

[11] Propp, Vladimir. (1989). Morphology of the Folk Tale, Trans. Fereidune Badreei, Tehran: Toos.

[12] Schols, Robert. (2004). Structuralism in Literature, An introduction, Trans. Farzane Taheri, Tehran: Markaz.

[13] Selden, Raman, and peter Widdowson. (2005). A readers Guide to Contemporary Literary Theory, Tehran: Tarhe Now.

[14] Sojoodi, Farzan. (2004). Applied Semiotics, Tehran: Ghesse.

[15] (2005). Semiotics and literature, Tehran: Farhange Kavosh.

[16] Toolan, Micheal. (2007). Narrative a Critical Linguistic Introduction, Trans. Fateme Alavi and Fateme Nemati, Tehran: Samt.

[17] Tyson, Loise. (2008). Cirthical theory a user..., Trans. Maziyare Hoseinzade and Fateme Hoseini, Tehran: Hekayate Ghalame novin.

[18] Warner, Marina. (2004). World of Myths, Trans. Abbase Mokhber, Tehran: Markaz. 